\title{
URBAN COASTAL DEVELOPMENT IN VALENCIAN COUNTRY: A PARADIGMATIC CASE OF NON-SUSTAINABLE DEVELOPMENT
}

\author{
J.L. MIRALLES I GARCIA \\ Department of Urban Planning, Polytechnic University of Valencia, Spain.
}

\section{ABSTRACT}

The period between 1997 and 2007 was a period of economic expansion in Europe, and especially in Spain, where it was based on the real-estate bubble. Valencian Country, in Mediterranean coast, is a special case inside Spain because its economy specialized in the housing construction sector for non-primary houses. House construction was possible due to the increase in private debt of developers and buyers. The (artificially self-generated) expectation of strong annual increases in housing values maintained an intense construction activity. In 2007, the price of houses peaked and then began a process of impoverishment due to the payment of debts. Today this process is still continuing, but extensive data on the complete cycle of expansion and regression of the housing bubble are already available. This paper presents a real description of the complete process of non-sustainable urban development in Valencian Country and analyzes the process in economic, social and environmental terms. Finally, a general scheme of the process and a system of sustainability is proposed.

Keywords: Housing market, property rights, real-estate bubble, sustainable urban development.

\section{INTRODUCTION}

After the Spanish Civil War (1936-1939), Franco's dictatorship began. When the Second World War ended in 1945, the Spanish State became economically isolated from the rest of the world (economic autarky). In 1959, the Spanish State was on the verge of bankruptcy. Thus, Spain needed to obtain foreign loans and needed foreign currency and investments.

To access loans from international banks, the government drafted and implemented an economic Plan of Stabilization [1] to promote industry by means of foreign investments. Among the measures provided for in the Plan, the promotion of tourism was included. As a result, the borders - until that time closed to the passage of goods and people - opened in 1959, in order to allow the entry of tourists in Spain. This was the beginning of the development of tourism in Spain.

In 1963, the Centres and Zones of Tourist Interest Act [2] was passed. This Act regulated the first tourist urban zones to be developed with public subsidization. The most important urban promotion, and a paradigmatic example and role model for the whole country, was La Manga [3], in the southeast of Spain, near the southern border of Valencian Country (Fig. 1).

These actions led to the first real-estate bubble in Spain. In fact, in Spain, we have been through three expansive economic cycles with three real-estate bubbles, as you can see in Table 1.

The crash of the first speculative bubble had political consequences, such as the end of the dictatorship and the beginning of democracy with the 1978 Constitution. Nevertheless, between 1991 and 1996, a second housing bubble occurred. Naredo Pérez [4] analyzed this process in detail.

The 1959-1972 bubble occurred due to the large influx of foreign capital produced by the economic Stabilization Plan. The 1985-1990 bubble occurred due to the large influx of European capital, which followed Spain's entry in the European Economic Community. The 1997-2006 


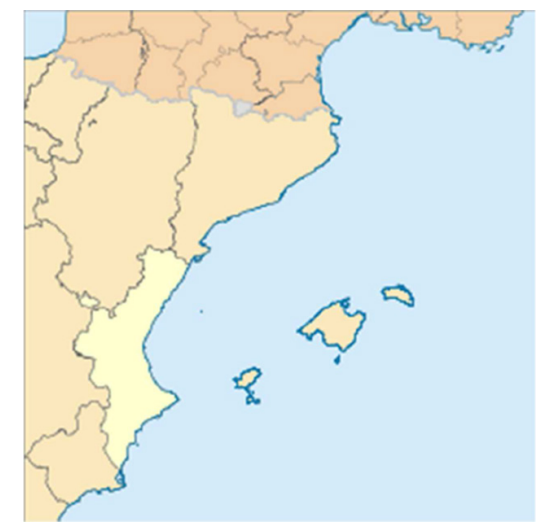

Figure 1: Geographical location of Valencian Country on the Mediterranean coast.

Table 1: Economic expansion cycles and real-estate bubbles in Spain.

\begin{tabular}{ll}
\hline Expansive economic cycles & Regressive economic cycles \\
\hline From 1959 to 1972 & From 1972 to 1984 \\
From 1985 to 1990 & From 1991 to 1996 \\
From 1997 to 2006 & From 2007 to present \\
\hline
\end{tabular}

All the phases of expansive cycles have been associated with speculative real-estate cycles

bubble took place due to the large capital inflows generated by the introduction of the euro as the single European currency, simultaneously with the free international movement of capital.

The 1997-2006 bubble was the third real-estate bubble in Spain and the most intense one. The data are spectacular. Valencian Country is an autonomous region in eastern Spain, with a surface of 23,700 $\mathrm{km}^{2}$ and $644 \mathrm{~km}$ of Mediterranean coastline [5]. Since the start of tourism development in Spain, Valencian Country has specialized in the tourism sector and construction associated with its promotion. In fact, Burriel de Orueta [6] and Zornoza Gallego [7] show how the process of housing bubble and its effects have been most intense in the Spanish provinces of Mediterranean coast and refer to several Spanish authors who have studied the economic aspects of the housing bubble in Spain. Thus, Valencian Country is a paradigmatic case of urban coastal development in the Mediterranean coast because most of its urban development has occurred in the coast [8]. Many Spanish authors have analyzed the economic aspects of the housing bubble [9-11]. But we can also consider the process as a case of non-sustainable development and analyze their characteristics and their consequences.

\section{RESEARCH OBJECTIVES AND METHODOLOGY}

Valencia's case is also a paradigmatic case of this speculative process or a good example of nonsustainable development. This paper shows the results of research on this process. The research objectives were to characterize the process of this non-sustainable development with a cycle of rapid economic growth and subsequent long-term impoverishment, identify the underlying causes that explain the process and extrapolate the scheme of real-estate bubbles to general cases of environmental bubbles. 
Analysis of time series data about economic indicators, analysis of behavior of social actors involved in urban development processes based on the laws regulating them and comparative analysis between the unsustainable process of the housing bubble and unsustainable processes caused by excessive consumption of natural resources.

\section{NON-SUSTAINABLE URBAN DEVELOPMENT PROCESS IN VALENCIAN COUNTRY AND SPAIN: BOOM AND CRASH}

\subsection{Housing construction in Valencian Country and Spain}

All non-sustainable development is based on resource consumption for an interval of time, in amounts above its restocking fee. In the case of urban development processes in Valencia and Spain, the resources consumed in amounts above their restocking fee are loan and mortgage granted without any possibilities of return.

Table 2 shows the evolution of housing starts year by year in Valencian Country and Spain. The period 1991-1996 was the last regressive cycle, and around 1997, the period of real-estate boom began, finishing in 2006. In 2007, the real-estate market crashed, thus giving way to the regressive cycle, which still exists today.

As shown in Table 2, the percentage of Valencia's population with regard to the total Spanish population is $10-11 \%$. In contrast, in the period 1997-2007, the percentage of housing starts in Valencian Country compared to those initiated in Spain was around 13\%. That is, in this period, Valencia specialized in residential construction, particularly in the construction of second homes for domestic or foreign population in coastal zones [12]. About $40 \%$ of dwellings in Valencian Country are second homes. In fact, the indicator has evolved from $41.66 \%$ in 2001 to $38.08 \%$ in 2011 and show the economic specialization in construction and tourism.

\subsection{Housing prices and the real-estate bubble}

This extraordinary urban expansion occurred as a result of a real-estate bubble process [13]. The creation of this bubble is based on debt. Banks lent money to dwelling buyers and developers. Initially, at the end of the last crisis (around 1996-1997), in a situation of equilibrium prices, loans generated money flows and housing prices tended to rise.

Figure 2 shows the evolution of average free-market housing in Spain and Valencian Country. As long as the rising trend went on, the banks lent money to buyers and developers, which was justified by the statistical trend of housing prices.

Thus, the mortgage had the trend of housing prices as a guarantee, but not the particular economic activity of the buyer. The banks lent money to the buyers for $100 \%$ or more of the housing value because they thought that if the buyer did not pay, they would get back the house and sell it for a higher price according to the trend. In fact, the statistical analysis based on trends of housing prices during the period 1997-2007 is a case of self-deception.

Note that in Spain, when a buyer cannot pay the mortgage, the bank obtains the house and has the right to sell it, but the commitment to repay the loan is maintained. The proceeds of the sale of the house are used to reduce a part of the loan. Thus, during the boom, banks lent up to $100 \%$ of the housing price to the buyers when the price was at its peak. After the crash, if the buyer could not pay, the bank got the house and sold it when the price was lower, but the loan was not cancelled and the buyer had to pay the difference between the result of the sale and the unpaid loan. 
Table 2: Housing starts every year in Valencian Country and Spain.

\begin{tabular}{ccccc}
\hline Year & S & VC & \% VC/S & $\begin{array}{c}\text { Population } \\
\text { VC/S }\end{array}$ \\
\hline 1991 & 205,580 & 28,413 & 13.82 & - \\
1992 & 196,653 & 25,889 & 13.16 & - \\
1993 & 188,953 & 24,996 & 13.23 & - \\
1994 & 247,211 & 29,410 & 11.90 & - \\
1995 & 305,724 & 37,001 & 12.10 & - \\
1996 & 301,796 & 34,507 & 11.43 & 10.11 \\
1997 & 343,365 & 40,852 & 11.90 & - \\
1998 & 425,974 & 51,390 & 12.06 & 10.10 \\
1999 & 509,086 & 67,379 & 13.24 & 10.12 \\
2000 & 540,128 & 73,542 & 13.62 & 10.17 \\
2001 & 528,472 & 69,002 & 13.06 & 10.22 \\
2002 & 536,590 & 71,160 & 13.26 & 10.34 \\
2003 & 591,459 & 75,990 & 12.85 & 10.47 \\
2004 & 675,887 & 92,721 & 13.72 & 10.52 \\
2005 & 698,458 & 94,139 & 13.48 & 10.64 \\
2006 & 725,801 & 99,275 & 13.68 & 10.75 \\
2007 & 599,631 & 80,082 & 13.36 & 10.81 \\
2008 & 306,546 & 33,726 & 11.00 & 10.90 \\
2009 & 148,134 & 9,599 & 6.48 & 10.90 \\
2010 & 121,401 & 7,990 & 6.58 & 10.87 \\
2011 & 110,264 & 7,446 & 6.75 & 10.84 \\
\hline
\end{tabular}

S, Spain; VC, Valencian Country.

Source: Instituto Nacional de Estadística (Spain) and author.

\subsection{Evolution of gross domestic product}

The large increase in housing construction and civil works implied a significant gross domestic product (GDP) growth of 3-4\% every year. This growth was based on private debt growth. However, at the same time, during the period 2000-2007, the increase in the price of free-market housing, which represented between $80 \%$ and $90 \%$ of housing starts each year, increased between $15 \%$ and $19 \%$ each year.

The high values of the increase in housing prices had a 'sinking effect' on the investment and productive economic activity. The investment was directed towards the construction of housing, thus further fueling the housing bubble. All this occurred in an international context of financial globalization, in which capital could move freely without restriction or control. 


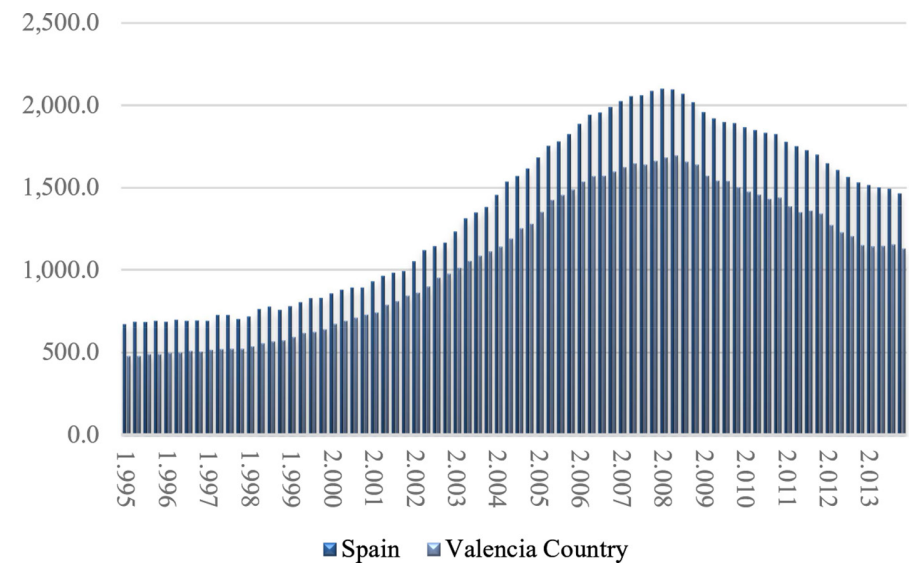

Figure 2: Evolution of average prices for free-market housing. Source: Ministerio de Fomento (Spain).

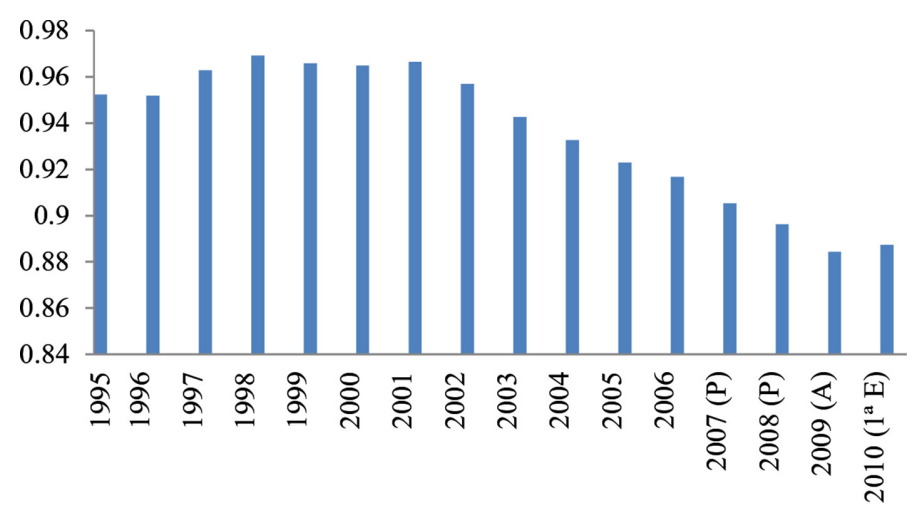

Figure 3: GDP percentage per capita in Valencian Country regarding the Spanish average (dates for 2007-2010 provisional, advanced or estimated). Source: Instituto Nacional de Estadística (Spain).

The investment in productive sectors of economy also decreased, with significantly lower yields. This explains the paradoxical fact that during the boom period, GDP per capita in Valencian Country went down steadily, if compared to GDP per capita in Spain, as seen in Fig. 3 [14].

This is a curious and paradoxical fact because during the time of the boom, when there was a large number of urban development being executed or planned, widespread social perception was of great optimism: everything was possible and there was money for everything. In contrast, today, the data show that during the boom period, the Valencian population was impoverished as compared with the Spanish population [14].

Coherently, when the crisis arrived and the urban construction sector collapsed, the unemployment rate in Valencian Country was higher than that in Spain and remains so today. 
This is a clear case of non-sustainable development because of two main reasons. On the one hand, the urban development was based solely on the expectations of a good market but not on satisfying real or objective demands of physical goods.

On the other hand, the housing production was based on debt, that is, on the current consumption of future monetary assets. Thus, society was mortgaging its future.

\subsection{Other questions about economic development during phase expansion}

In Spain, from 1976 Land Act, owners pay urbanization costs, transfer urbanized land to administration and obtain land in good conditions to build. Owners add urbanization costs in the sale price of housings or buildings. If housing production is less than quantity corresponding to the market equilibrium level for real demand, system function and administration obtain without pay, streets and green zones already urbanized and land for public facilities. However, land urbanized in excess without buildings or with buildings without uses produces maintenance costs for administration without income. It is a non-sustainable situation.

However, in coastal zones where a high demand of housing for tourist activities exists, the equilibrium level of building market can produce, in fact, an excess of housing and overcrowding. This phenomenon occurs and generates negative effects after house construction where the correction of negative effects is very difficult as has happened in the case of La Manga already noted. In this case, housing market does not produce a sustainable situation of economic tourist activity.

Maybe, a quality certification system, as developed in the European project QUATER [15] realized to promote the quality of territory face up to risks, can help achieve territories with landscape quality and services for tourism. However, these procedures do not address the root causes of the problem.

\section{CAUSES THAT EXPLAIN THE PROCESS}

\subsection{The land market for housing construction}

The behavior of the land market for housing construction deserves special attention. In Spain, regulation of property rights is based on the theory of the social function of property. From 1978's Constitution, private property is limited by its social function. In the case of land property, urban planning defines its social function. When urban planning defines a zone as 'urbanizable' or 'suitable to be urbanized', works to urban develop the area are considered to be of public interest. In this case, landowners or public administration can develop the area, but in any case, landowners may object to the urban development of the area.

However, in 1994, the regional government of Valencian Country developed a special system to manage this kind of land [16] by a new agent called 'development agent'. Any urban developer can propose the local administration (municipality) to develop an urban sector without owning the land. By a complex administrative procedure in which other developers can present their own proposals, the municipality selects the 'development agent'. The developer finances the urbanization works and pays landowners according to the land valuation included in his proposal, which has previously been approved by the local administration. In any case, if the owners do not agree, they can claim justice. Usually, the court valuates according to the land market. The owners also pay the developer of urbanization works by money or by land in the same sector and receive buildable plots.

On the other hand, we must consider the fact that market for land to build and rural land market are very different. Housing is a good produced by a company. In contrast, land necessary to build is, 
really, underground under the building, that is, a natural good not produced by anyone. Thus, the price of housing determines the price of land, and the price of land for building is always speculative.

In fact, the developer pays for the ground in order to destroy it, to remove it and get the underground to use as a support for foundation works. Our society confuses the ground and the underground when, in fact, they are two substantially different goods. The ground is on the surface and it can be observed; it is part of the landscape and can be improved by the owner for agricultural or rural uses. In contrast, the underground cannot be seen, it is not part of the landscape, it is a natural good, no one produces it and it has no production costs.

If we consider that the only real source of society's wealth is work, as already noted by Adam Smith in the 18th century [17], paying for goods or services, which no one produces, is an economically irrational rule that can only produce society's misery because it is paid for doing nothing. This sentence has been proved in the case of the last real-estate boom in Valencian Country and Spain.

In fact, during the boom, an important part of the price of housing was used to pay for the ground. For example, on the border of the city of Valencia, the price of rural land for urban development went up to $180 € / \mathrm{m}^{2}$. Today lands purchased for maximum values have no market value because there is no willing buyer. It is difficult to know precisely the value of the amount of land purchased in Spain with the expectation to build but is estimated at 50,000 million $€$ in bank assets valued at purchase cost [14]. Today, the market value of these lands is zero or very low and consequently, the whole society has been depleted by an amount equal to the loss of the value. If this investment had been made in productive sectors of economy, it would have produced an increase in GDP in the longer term.

Demsetz [18] showed how changes in technology and economic relations generated changes in the concept of ownership. Maybe, it is time to change the idea of land ownership to ensure future economic progress. The landowner must own the surface of the land, the ground, namely the ground that is removed during the process of urbanization. However, he does not own the underground or the geographic coordinates. That is, the owner has the property resulting from their work. Equally, the builder must own the building but not underground or geographic coordinates. Thus, private ownership of the building will remain until ruin occurs. Current Geographic Information Systems technology allows registration and monitoring real situation of any process of change of use in the entire territory.

\subsection{Other aspects of the process}

The process of non-sustainable urban development has economic, social, environmental and governance dynamics [13]. While the previous sections have identified the most significant economic issues, let us now point out other aspects.

From the social point of view, during the boom, the population did not perceive the process. It even rejected public opinion warnings of the risks. For example, in 2003, the Bank of Spain published a study that concluded that the housing price was $30 \%$ above its normal value [19]. This paper generated a public debate. Most political and economic agents felt that the economy was doing well and that reality contradicted the findings of the study. Thus, during the boom, the society and the population lived with great optimism about the future and tended to ignore the risks.

From the environmental point of view, the main effects are the virtually irreversible nature of an excessive urban transformation and urban sprawl, especially in coastal zones [7,8,20]. Nowadays, there is a contradictory situation. On the one hand, tourism activity is growing and, in 2013, Spain received a record number of 60.6 million tourists. On the other hand, many studies show signs of exhaustion of the tourism model in coastal zones. The question is: promoting more visitors or 
promoting quality? Promoting growth, more housing, and more urban expansion? Or promoting quality of landscape and services? For me, in the current situation, in general, it is better to promote quality.

From the governance point of view, we have a very problematic situation. Since the Land Act of 1975 was passed, municipalities can usually obtain incomes by urban development. For a long time, this practice has served as an incentive for municipalities to promote activities, especially in coastal municipalities. This practice has also been used to make up for the shortage of public services.

However, in the last boom, municipalities often used this practice for the sole purpose of obtaining income, regardless of the need or objective justification for new urban developments. Bear in mind that any new urban development produces income at the initial stages and expenses in the future. The study on the case of La Manga [3] shows how the urban development without limit, finally, produces landscape degradation, massive tourism and revenue decline. Furthermore, once it has reached the stage of degradation, it is very difficult to reverse the situation.

The current system of governance or organization of public administration has been unable to guarantee society's interest in the long term. There have also been numerous cases of political corruption associated with land speculation [21].

\section{SUSTAINABILITY ANALYSIS AND EXTRAPOLATION SCHEME}

\subsection{Analysis and consequences of excessive urban development}

The urban development, which took place during the boom, was non-sustainable. It is a clear case of non-sustainable development, that is, development to satisfy society's needs in the boom period, which mortgaged the possibilities of future generations, today present, to satisfy their own needs.

In the case of urban development, we can consider a point of equilibrium in housing production when production satisfies normal current needs. If housing production is greater than the equilibrium value and besides, it is paid with debt, then you are paying present development with future resources.

In Valencian Country and Spain, the period 1996-1998 is the end of the crisis and the beginning of the boom. It is a period of equilibrium. The number of housing starts for this period is between 200,000 and 250,000 free-market housing for Spain and 22,000 and 27,500 free-market housing for Valencian Country [14]. According to this hypothesis, housing starts each year above the equilibrium value generate a glut of houses.

Please refer to Miralles [12] if you want to see more significant variables of the process of urban development in Valencia and Spain (average prices, distribution of houses in principal and nonprincipal, construction share in GDP and evolution of unemployment rate),

We can also calculate the monetary value of all these excess real-estate assets using the average values of the sales price of housing for each year. However, the buyer can buy before starting the construction of the house, during the period in which the house is being built or after completion of the construction. The price of housing is different at each moment. To delimit the range of variation, we can also calculate the monetary value using housing finished each year with average values of the sales price in the final year of construction.

Tables 3 and 4 show the results of these calculations for the free-market housing [14]. In Spain we have two housing markets: a general free-market and a market of subsidized houses with official prices. In the period 1997-2008, and depending on the year, the free-market houses built amounted to a percentage between $80 \%$ and $90 \%$ of the total number of houses built. Moreover, the price of subsidized housing during the boom was far lower than the price of private housing; 
Table 3: Excess housing starts in Valencian Country and Spain.

\begin{tabular}{|c|c|c|}
\hline Housing market parameter & Valencian Country & Spain \\
\hline $\begin{array}{l}\text { Excess free-market housing in } 2007 \text { that was started between } \\
1997 \text { and 2008; equilibrium level of 22,000 housing/year } \\
\text { in Valencian Country and 200,000 housing/year in Spain, } \\
\text { number of housings }\end{array}$ & 471.383 & 3.367 .072 \\
\hline $\begin{array}{l}\text { Number of years since } 2007 \text { without starting any housing to } \\
\text { return to equilibrium }\end{array}$ & 21,43 & 16,84 \\
\hline Nominal value of the excess, million euros & $54.933,6$ & $448.070,9$ \\
\hline $\begin{array}{l}\text { Excess free-market housing in } 2007 \text { that was started between } \\
1997 \text { and 2008; equilibrium level of } 27,500 \text { housing/year in } \\
\text { Valencian Country and 250,000 housing/year in Spain, num- } \\
\text { ber of housings }\end{array}$ & 405.383 & 2.767 .072 \\
\hline $\begin{array}{l}\text { Number of years since } 2007 \text { without starting any housing to } \\
\text { return to equilibrium }\end{array}$ & 14,74 & 11,07 \\
\hline Nominal value of the excess, million euros & $47.875,4$ & $372.918,1$ \\
\hline
\end{tabular}

Source: Instituto Nacional de Estadística (Spain) and author.

Table 4: Excess of finished housing in Valencian Country and Spain.

\begin{tabular}{|c|c|c|}
\hline Housing market parameter & $\begin{array}{l}\text { Valencian } \\
\text { Country }\end{array}$ & Spain \\
\hline $\begin{array}{l}\text { Excess free-market housing in } 2007 \text { that was finished between } 1997 \\
\text { and 2009; equilibrium level of 22,000 housing/year in Valencian } \\
\text { Country and 200,000 housing/year in Spain, number of housings }\end{array}$ & 453.320 & 3.041 .394 \\
\hline $\begin{array}{l}\text { Number of years from } 2007 \text { without starting any housing to return to } \\
\text { equilibrium }\end{array}$ & 20,61 & 15,21 \\
\hline Nominal value of the excess, million euros & $62.794,8$ & $454.421,4$ \\
\hline $\begin{array}{l}\text { Excess free-market housing in } 2007 \text { that was finished from } 1997 \text { to } \\
\text { 2009; equilibrium level of } 27,500 \text { housing/year in Valencian Country } \\
\text { and 250,000 housing/year in Spain, number of housings }\end{array}$ & 381.820 & 2.391 .394 \\
\hline $\begin{array}{l}\text { Number of years from } 2007 \text { without starting any housing to return to } \\
\text { equilibrium }\end{array}$ & 13,88 & 9,57 \\
\hline Nominal value of the excess, million euros & $54.708,9$ & $369.672,1$ \\
\hline
\end{tabular}

Source: Instituto Nacional de Estadística (Spain) and author.

Housing market parameterby the Ministerio de Fomento (Spain), based on all appraisals performed by appraisal associations [22].

The results are very similar in both scenarios. Depending on the scenario, the excess of housing in Spain in the boom period is between 2,391,000 and 3,367,000 housings with a nominal value between 369,000 and 448,000 million $€$. For Valencian Country, the results are an excess between 382,000 and 471,000 housings with a nominal value between 48,000 and 63,000 million $€$. 
If we consider that the GDP of Spain is approximately 1,000,000 million $€$ and for Valencian Country it is approximately $10 \%$, the proceeds are important.

During the boom period, the Valencian Mediterranean coast specialized in the construction sector, particularly in non-principal residences or second homes (in the period 2005-2011, around 38\% of housings were non-principal). Therefore, the consequences of the crisis were more intense.

If we consider that housing starts each year above the equilibrium value as an excess of houses, we can calculate the number of years that society needs without housing starts, to return to equilibrium.

According to the two different scenarios, Spain needs between 10 and 17 years to return to equilibrium and Valencian Country between 14 and 21 years. These calculations demonstrate the magnitude of the process. In fact, today in 2014, 7 years after the beginning of the crisis in 2007, housing prices in Spain are still decreasing. This indicates that there is still an oversupply of housing.

On the other hand, the average housing price in 1997 in Spain was around $700 € / \mathrm{m}^{2}$. If we consider this price as an equilibrium price and an average increase in consumer price of $2.5 \%$ each year (average of general Consumer Price Index between 1997 and 2007 was 3.92\%, but in the period of recession 2008-2011, the average was 2.2\%), the new equilibrium price in 10 or 16 years after 2007 will be $1,150-1,350 € / \mathrm{m}^{2}$. In 2013 , the average housing price went down from $2,100 € / \mathrm{m}^{2}$ to $1,500 € / \mathrm{m}^{2}$. Therefore, the downside can still get deeper.

\subsection{Environmental analogy and extrapolation scheme}

Figure 4 shows a general scheme of sustainability processes for natural resource consumption [12]. Really, the idea is very simple and based on the natural capital concept [23].

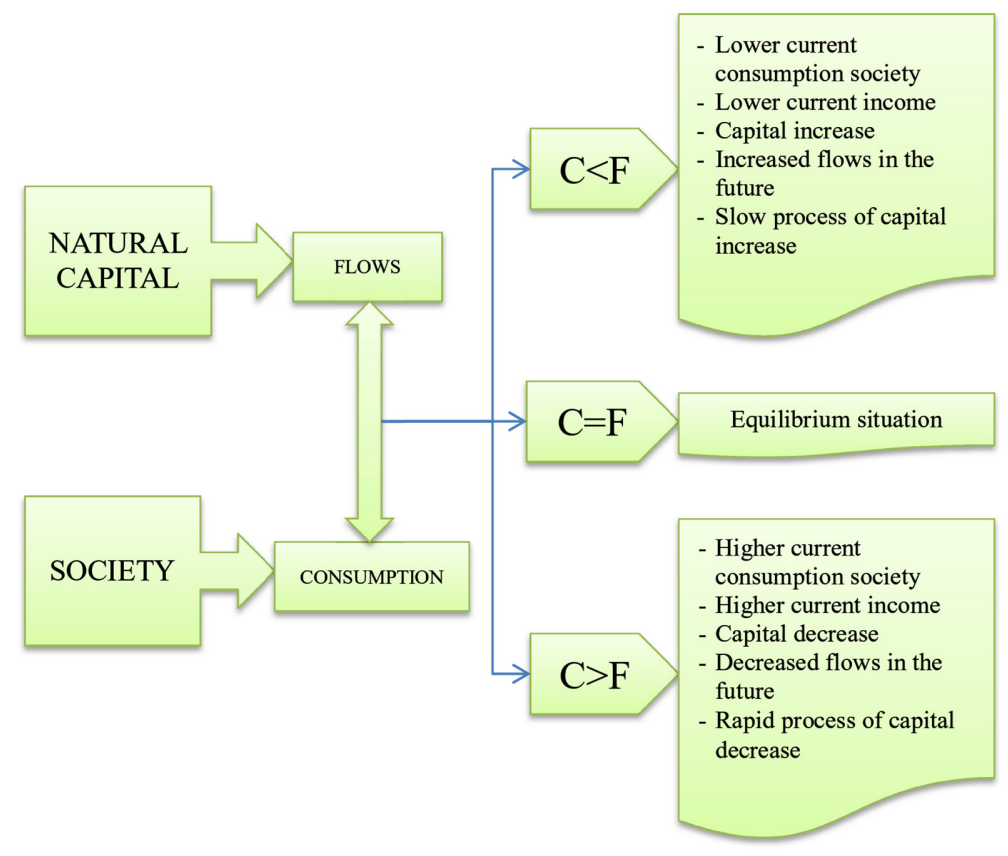

Figure 4: General scheme of sustainability processes. 
We can imagine an isolated society (in fact, the world's society is economically isolated except in the case of solar energy). Society has a natural capital, that is, an asset of natural resources. These natural resources produce each year a flow of all kinds of natural goods. Also, each year, this society consumes a quantity of natural goods for economic activities.

If society's consumption is greater than the flow of natural goods, economic activity is not sustainable.

In contrast, if society's consumption is lower than the flow of natural goods, economic activity is sustainable. In addition, natural capital increases and, consequently, the flow of natural goods can increase in the future.

However, these conditions for sustainability generate a very important problem. In a nonsustainable situation, society's consumption is greater than that in a situation of sustainable consumption. That is, at the present time, society in a non-sustainable situation has a higher level of economic well-being than society in a situation of sustainability. Or, in other words, society in a situation of non-sustainability can undergo a greater increase in GDP than society in a sustainable situation at the present time.

Current consumption of natural resources above the replacement rate produces a decrease in natural capital and a decrease in future flows of natural goods produced by that capital.

Frequently, society and governments want to increase GDP at the present time. This social behavior generates a trend towards unsustainable development.

In Fig. 5, you can see the scheme of non-sustainable dynamics. In time $\mathbf{t}$, society has a Stock of natural resources (natural capital), which produces a Flow of natural goods for a period. If society's Consumption is greater than the Flow, then the Stock decreases in time $\mathbf{t}+\mathbf{1}$.

Later, if society wants to increase the Flow of natural goods in the future, then the Consumption of the Flow must decrease in order to increase the Stock. This decrease in society's Consumption of natural resources would probably generate a decrease in GDP.

It is possible to draw an analogy between environmental sustainability and economic sustainability. We can consider that society has an economic activity. This economic activity is equivalent to the stock of natural resources.

With a given level of economic activity (the economic base that produces GDP), society has a debt capacity. That is, society can borrow up to a certain amount without lowering its level of economic activity or economic base because society can repay the loan and interest. The debt capacity of society is equivalent to the flows of natural capital.
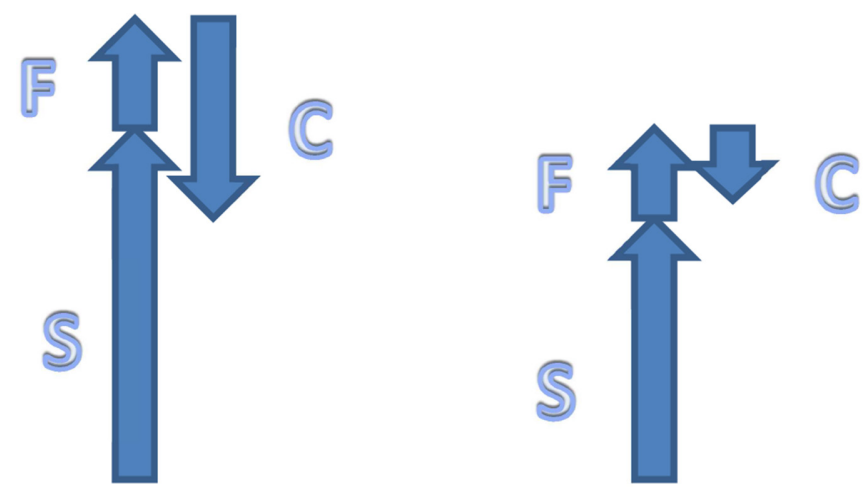

Figure 5: Dynamics of non-sustainable development. 
Finally, society will have a real debt. If society's debt is greater than its debt capacity, then the economic activity or economic base will go down.

For example, during the real-estate boom in Spain and Valencia, society increased debt in order to produce and buy housings. The number of houses produced by debt was greater than the amount that could be paid with the existing level of economic activity. Thus, society acquired an excess of debt.

When in the past, society obtained loans or mortgages, then society received money incomes, produced a lot of houses (in fact, an excess of houses) and the GDP increased. Later, society must pay the excess of debt. The excess of houses built produces a decrease in the construction sector and a decrease in the economic activity or economic base.

Figure 6 shows the evolution of non-financial debt in Spain (in €), the evolution of GDP (in €) and the evolution of housing starts for building each year. In the boom period, the trends of the three variables were parallel. This is further evidence that relates GDP growth with the growth of excess debt.

After the crash in 2007, debt stopped, and both house construction and GDP decreased. Then society had to pay the excess debt.

As already noted, the monetary income generated by excess debt is equivalent to the monetary income generated by the exploitation of natural resources. Both produce a current increase in GDP, but this increase is only conjunctural. In fact, this increase in GDP is obtained by sacrificing the production of goods and services in the future. Therefore, the Spanish and Valencian case can be taken as a reference to a process of non-sustainable economic development and the consequences it produces.

Perhaps, the main difference between a process of non-sustainable development caused by excess debt and non-sustainable development caused by excess natural resource consumption is that, in the first case, it is a social process. It is a process caused by the behavior of social and economic agents.

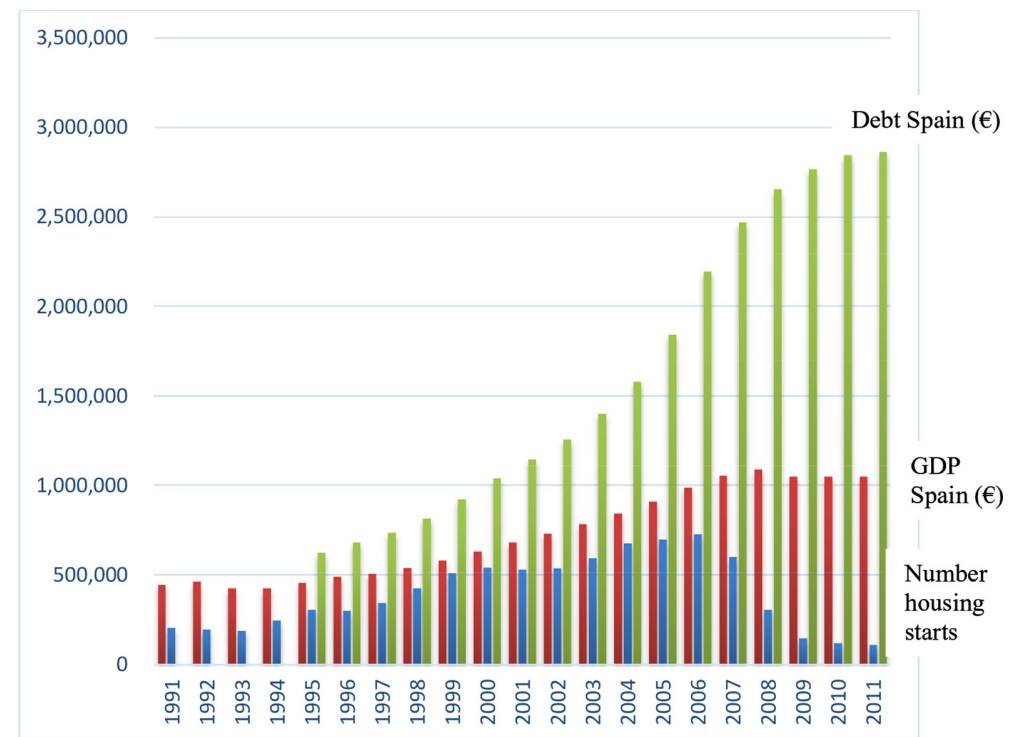

Figure 6: Parallelism in the dynamics of non-financial debt of Spain (euros), GDP (euros) and the number of housing starts each year. Source: Banco de España (Spain), Instituto Nacional de Estadística (Spain) and author. 
Consequently, in theory, it can be regulated and controlled by social and economic rules and policies. The control of these processes only depends on society itself.

In contrast, in the second case, it is a physical process. The depletion of natural resources, when it occurs, is a physical process. In this case, the change in social and economic policy rules may not be enough. When oil is exhausted, there will be no more. If a species becomes extinct, it is virtually impossible to recover. Only new technologies, when available, can replace resources.

\section{CONCLUSIONS}

In Spain there was a spectacular urban development during 1997-2007, especially on the Mediterranean coast for second homes market. In particular, this phenomenon was more intense in Valencian Country. This extraordinary urban expansion occurred because of a real-estate bubble process. The creation of this bubble was based on excess debt.

The Valencian Country case allows a detailed analysis of a paradigmatic process of non-sustainable urban development. Today we have a lot of data and a detailed analysis is possible. According to this analysis, we can conclude:

- Non-sustainable development is based on excess resource consumption. It is possible to consider a general theory about sustainable development for an economic or environmental situation.

- Therefore, we can consider that there exists an equilibrium level for resource consumption.

- In the case of urban development or housing construction, the equilibrium level is the number of dwellings that market can absorb in a normal situation. As usually access to housing, in Spain, is by mortgage, the equilibrium level is equivalent to debt capacity with guaranteed return.

- We must differentiate between the ground and the underground. The ground is on the surface and the owners can improve it. In contrast, the underground to build buildings or civil works is a natural good that no one produces. In a case study, propriety of this natural good generates speculative economy and finally society's misery.

- A case study shows that non-sustainable development generates significant income in the phase of excess consumption of resources at the expense of decreased revenues in the future due to lack of resources.

- The excess of houses in coastal zone can produce overcrowding of tourism in an irreversible manner and, consequently, a reduction in revenue per visitor.

- According to a case study, society and governments want to increase GDP at the present time during the phase of bubble expansion. This social behavior generates a trend towards unsustainable development. This fact shows the need to generate some independent power (environmental power) to ensure long-term development and avoid excess consumptions.

\section{REFERENCES}

[1] Tamames Gómez, R., Introducción a la economía española, Alianza Editorial: Madrid, 2005, ISBN 9788420658353.

[2] Terán Troyano, F., Planeamiento urbano en la España Contemporánea (1900-1980), Alianza Universidad Textos: Madrid, 1982, ISBN 9788425207112.

[3] Miralles, J.L. \& García-Ayllón, S., The economic sustainability in urban planning: case La Manga. WIT Transactions on Ecology and the Environment, 173, pp. 279-290, 2013. doi: http://dx.doi.org/10.2495/sdp130231

[4] Naredo Pérez, J.M., La burbuja inmobiliaria-financiera en la coyuntura económica reciente (1985-1995), Siglo XXI de España Editores: Madrid, 1996, ISBN 9788432309137. 
[5] IVE (Instituto Valenciano de Estadística), Generalitat Valenciana, 2014, www.ive.es

[6] Burriel de Orueta, E., El estallido de la burbuja inmobiliaria y sus efectos en el territorio. Geografia de la crisis económica en España, Universitat de València, Servei de Publicacions: Valencia, pp. 101-140, 2014, ISBN 9788437093611.

[7] Zornoza Gallego, C., Crecimiento urbanístico en la zona costera de la Comunidad Valenciana (1987-2009), PUV Universitat de València: València, 2013, ISBN 9788437090702.

[8] Miralles i Garcia, J.L., Díaz Aguirre, S. \& Altur Grau, V.J., Environmental impact on the Mediterranean Spanish coast produced by the latest process of urban development. WIT Transactions on Ecology and the Environment, 155, pp. 379-389, 2012. doi: http://dx.doi.org/10.2495/sc120321

[9] Garcia Montalvo, J., De la quimera inmobiliaria al colapso financiero, ed. A. Bosch, S.A.: Barcelona, 2008, ISBN 9788495348449.

[10] Miguel, M., La crisis inmobiliaria. Economistas, 119, pp. 256-265, 2009.

[11] Rodríguez López, J., Los booms inmobiliarios en España. Papeles de economía española, 109, pp. 76-90, 2006.

[12] Miralles i Garcia, J.L., Contributions to a theoretical framework for sustainable urban development: some conclusions of the Spanish case. WIT Transactions on Ecology and the Environment, 179, pp. 199-210, 2013. doi: http://dx.doi.org/10.2495/sc130171

[13] Miralles i Garcia, J.L., Real estate crisis and sustainability in Spain. WIT Transactions on Ecology and the Environment, 150, pp. 123-133, 2011. doi: http://dx.doi.org/10.2495/sdp110111

[14] Miralles i Garcia, J.L., El darrer cicle inmobiliari al País Valencià. O el progrés de la miseria, Fundació Nexe: Barcelona, 2014, ISBN 978-84-940877-2-1.

[15] Miralles i Garcia, J.L. et al., El projecte QUATER: un projecte europeu per la Qualitat del territory front als riscos, Editorial UPV: València, 2004, ISBN 84-9705-556-X.

[16] Miralles i Garcia, J.L., Sustainability regulations in urban planning: the experience of the Autonomous Community of Valencia (Spain). WIT Transactions on Ecology and the Environment, 120, pp. 3-12, 2009, doi: http://dx.doi.org/10.2495/sdp090011

[17] Smith, A., La riqueza de las naciones, Alianza Editorial: Madrid, 2013, ISBN 987-84-2065096-8 [Original publication: An Inquiry into the Nature and Causes of the Wealth of Nations, London, 1776].

[18] Demsetz, H., Toward a Theory of Property Rights. The American Economic Review, 57, American Economic Association, pp. 347-359, 1967, available at: http://www.jstor.org/discover/10 $.2307 / 1821637$ ?uid $=3737952 \&$ uid $=2 \&$ uid $=4 \&$ sid $=21104925495167$

[19] Martínez Pagés, J. \& Ángel Maza, L., Análisis del precio de la vivienda en España. Documento de trabajo $n^{\circ}$ 0307, Banco de España: Madrid, 2003, available at: http://www.bde.es/f/webbde/ SES/Secciones/Publicaciones/PublicacionesSeriadas/DocumentosTrabajo/03/Fic/dt0307.pdf

[20] Gaja i Díaz, F., Deconstruction. La desconfiguración del litoral mediterraneo español, Universitat Politècnica de València: Valencia, 2012, ISBN 978-84-8363-799-9.

[21] Martín Martín, V.O. \& Jerez Darias, L.M., La corrupción urbanística, la crisis actual y el atraso de España. El papel de la renta del suelo, Editorial Académica Española, 2011, ISBN 978-38-4735-282-9.

[22] Ministerio de Fomento (Spain), https://www.fomento.gob.es/MFOM/LANG_CASTELLANO/ATENCION_CIUDADANO/INFORMACION_ESTADISTICA/Vivienda/Estadisticas/ Precios/default.htm

[23] Wackernagel, M., Onisto, L., Bello, P., Callejas Linares, A., López Falfán, I.S., Méndez García, J. Suárez Guerrero, A.I. \& Suárez Guerrero, M.G., National natural capital accounting with the ecological footprint concept. Ecological Economics, 29, pp. 375-390, 1999. doi: http://dx.doi. org/10.1016/s0921-8009(98)90063-5 